\title{
Analytical Evaluation of Behavior of Composite Columns Under Axial Load
}

\author{
Serkan Etli \\ Munzur University, Faculty of Engineering, Departmant of Civil Engineering, Tunceli, Turkey \\ serkanetli@munzur.edu.tr (iD) \\ Received date:06.09.2021, Accepted date: 25.11.2021
}

\begin{abstract}
In the literature, various studies have been carried out for different nonlinear modeling strategies to model the response of such composite column members subjected to dynamic loads. In studies of concrete filled steel tubes elements with software using a finite element method such as ABAQUS, ANSYS and LS-DYNA, which have been used in the literature in recent years, it is seen that steel and concrete components are generally modeled separately with the help of plate, shell, or solid elements. To simulate the interaction between these element models, the help of some other connector or interface elements is needed. Therefore, the biggest disadvantage of using commercial packages is that very complex calculations arise by using much smaller parts of the element to be analytically modeled and the interaction structures to be produced between them. As a result, the necessity of computationally intensive and at the same time long-term work emerges. Within the scope of this study, it is aimed to calculate composite columns faster and more accurately as possible by using fiber section elements and standard material models under axial loading effects. It was observed that the selected parameters had a significant effect on the results obtained.
\end{abstract}

Keywords: Composite column, fiber section, material model

\section{Eksenel Yük Altında Kompozit Kolonların Davranışının Analitik Değerlendirilmesi}

\section{$\ddot{O} z$}

Literatürde, dinamik yüklere maruz kalan bu tür kompozit kolon elemanlarının tepkisini modellemek için farklı doğrusal olmayan modelleme stratejileri için çeşitli çalışmalar yapılmıştır. Literatürde son yıllarda kullanılan ABAQUS, ANSYS ve LS-DYNA gibi bir sonlu elemanlar yöntemi kullanan yazılımlar ile beton dolgulu çelik tüp elemanlarına ait çalışmalarda, çelik ile beton bileşenlerin genellikle plaka, kabuk veya katı elemanların yardımı ile ayrı ayrı modellendikleri görülmektedir. Bu eleman modellerinin aralarındaki etkileşimi simüle etmek için bazı diğer bağlayıcı veya arayüz elemanlarının yardımına ihtiyaç duyulmaktadır. Dolayısıyla, ticari paketler kullanmanın en büyük dezavantajı, analitik olarak modellencecek elemana ait çok daha küçük parçalar kullanılarak ve bunlar arasında üretilecek olan etkileşim yapıları nedeniyle çok karmaşık hesaplamalar ortaya çıkmaktadır. Sonuç olarak hesaplama açısından yoğun ve aynı zaman uzun süreli çalışma gerekliliği ortaya çıkmaktadır. Bu çalıșma kapsamında kompozit kolonların eksenel düşey etkiler altında fiber kesitli elemanlar ve standart malzeme modelleri kullanılarak daha hızlı ve mümkün olduğunca daha doğru hesaplanması hedeflenmiştir. Seçilen parametrelerin elde edilen sonuçlar üzerinde önemli derecede etkili olduğu gözlemlenmiştir.

Anahtar Kelimeler: Kompozit kolon, fiber kesit, malzeme modeli

\section{INTRODUCTION}

Concrete-filled steel column (CFST), which is reinforced by confinement effect with elements with steel tube sections and enhanced by utilizing the superior properties of concrete and steel, is normally used in concrete columns to meet the extra stresses that may occur due to structural effects. This technique can be used in the literature to increase the strength of an existing column in the structure, or it can be produced as a new element in high-rise buildings with large spans or designed on a large scale. (Etli \& Güneyisi, 2020, 2021; Li et al., 2018; Matsui, 1986). The higher ductility, higher rigidity and higher strength provided by CFST elements are used in earthquake resistant structures of these structures or in the construction of bridge piers that are often exposed to impact and dynamic loads (Etli 
\& Güneyisi, 2020, 2021; Lee et al., 2009; Shanmugam \& Lakshmi, 2001).

Experimental studies have been carried out on the behavior of CFST elements with different crosssection properties and geometries, such as circular, rectangular, elliptical, and square sections, under pure axial and eccentric compression, tension, and torsional forces, recently studied with CFST elements (Han et al., 2006, 2011, 2014; Lee et al., 2009; Ou et al., 2011; Perea et al., 2013; Shanmugam \& Lakshmi, 2001). Also, different codes (ACI (ACI 318-08, 2008), AISC (AISC, 2003) and EC4 (EN 1994-1-1, 2004)) included design provisions for CFST columns.

Many parameters affect the structural behavior of CFST elements, such as L/D and D/t ratios (L length, $\mathrm{D}$ core diameter and $\mathrm{t}$ wall thickness), material properties such as concrete strength and steel yield strength. Experimental evaluation of all these effects is not only expensive, but also very time-consuming. Therefore, in these elements, nonlinear finite element simulation approach may be the best solution to examine and account for all the effects mentioned (Liang \& Fragomeni, 2009).

In the literature, various studies have been conducted for different nonlinear modeling strategies to model the response of such composite column elements subjected to dynamic loads. In the modeling of CFST elements with a finite element package such as ABAQUS, ANSYS and LS-DYNA, steel and concrete components are generally modeled separately using a plate, shell, or solid elements. Then, these element models are combined with some binder or interface elements to simulate the interaction between steel and concrete. (Ellobody \& Young, 2006; Ge \& Usami, 1994; Han et al., 2007; H.-T. Hu et al., 2003; H. T. Hu et al., 2005; Schneider, 1998; Thai \& Kim, 2011; Ly et al., 2021; Asteris et al., 2021; Ayough et al., 2021). The main disadvantage of using commercial packages is that the structures become very complex due to very finely divided into smaller pieces and are therefore computationally intensive. In addition, it is difficult to properly and adequately model the composite behavior that occurs between steel and concrete, i.e. the interaction between concrete and steel materials, which is necessary to show interoperability limits (Thai \& Kim, 2011). Many composite beam and column models with different cross-sections have been developed by researchers in the literature under different behavior models. Tomii and Sakino (Tomii
\& Kenji, 1979) presented an analytical model for beams and columns produced as CFST with the help of elastic-plastic analysis. Considering the mentioned models and their experimental studies, detailed models for stress-strain developed by considering boundary effects for concrete confinement with steel pipe elements in CFST element are proposed. Hajjar et al. (Hajjar et al., 1998) proposed a model using a distributed plastic finite element based on fiber elements to perform nonlinear inelastic analysis of CFST beam columns.

In this study, CFST column elements were modeled in 3D with fiber section modeling technique and inelastic force-based frame element type elements were modeled in SeismoStruct (SeismoStruct, 2015) software. Some experimental studies under axial force in the literature were modeled using material models commonly used in the literature in element models, and the results obtained were examined comparatively.

\section{MATERIAL AND METHODS}

Within the scope of the study, the material models frequently found in the literature were used to evaluate the behavior of these elements quickly and reliably by making use of the square section column elements examined under axial force in the literature. While the Mander (Mander et al., 1988) concrete model was used for the concrete in the core parts of the CFST elements, square steel tubular elements were used in the outer parts. In these steel parts, the bilinear steel model and Ramberg-Osgood (Gadamchetty et al., 2016) steel material models, which are widely used in the literature, are used. The technical information and calculation techniques of the models used are presented in detail below.

\section{Material models}

The concrete model used in this study was developed by Martinez-Rueda and Elnashai (Martínez-Rueda \& Elnashai, 1997), and a concrete model that considers the behavior of concrete under cyclic loads was used while the model was being obtained. This model is defined as "con_ma" within the SeismoStruct software. In this study, the confinement effect on CFST columns is provided by steel SHS (square hollow section) at the outermost part of the element. The confinement effect is defined by the $\mathrm{k}_{\mathrm{c}}$ value in the selected concrete model of the SeismoStruct (Seismosoft, 2018) software. The confinement factor $k_{c}$ is described as the ratio of the 
compressive strength of the confined concrete model to the plain concrete strength. The confinement effect on the concrete cores of the CFST columns is provided by the steel SHS at the outermost part of the member. The $\mathrm{k}_{\mathrm{c}}$ value obtained from the confinement effect calculations is reflected in the concrete model of the SeismoStruct (Seismosoft, 2018) software.

The calculation methods given by Sakino et al. (Sakino et al., 2004) were used in the calculations of the axial pressure load capacity. While obtaining the equation, it is assumed that the strength capacity of $f_{c c}$ confined concrete, which is used in the calculation of the strength of the confined concrete, is calculated by Equation 1. In addition, the strength reduction factor was calculated with Equation 2 (Liang, 2009). In addition, the confinement coefficient given by $\mathrm{k}$ was considered as 4.1, as stated by Richart (Richart et al., 2005). On the other hand, $f_{c r}$ confining stress (lateral pressure), $\gamma_{U}$ (strength reduction factor for concrete), $f_{c c}$ (strength of confined concrete), $f_{c}{ }^{\prime}$ (concrete compressive strength), $f_{s y}$ (yielding strength of steel) is given in Equation 3 (Sakino et al., 2004).

$$
\begin{gathered}
f_{c c}=\gamma_{U} \times f_{c}{ }^{\prime}+k \times f_{c r} \\
\gamma_{U}=1.85 \times B_{c}{ }^{-0.135} \quad 0.85 \leq \gamma_{U} \leq 1 \\
f_{c r}=\frac{2 \times t^{2} \times(B-t) \times f_{s y}}{B_{c}{ }^{3}}
\end{gathered}
$$

The term $B$ in the equation is the section width of SHS, while $B_{c}$ refers to the section width of the concrete core, $t$ is the thickness of section. In addition, the $\varepsilon_{\mathrm{co}}$ (strain at maximum stress of concrete) value calculated for plain concrete is calculated as given in Equation 4 (Sakino et al., 2004).

$$
\begin{gathered}
\varepsilon_{c o}=0.94 \times\left(0.85 \times f_{c}^{\prime}\right)^{0.25} \times 10^{-3} \\
0.002 \leq \varepsilon_{c o} \leq 0.0022
\end{gathered}
$$

For the structural steel forming the outer shell of the CFST element, two commonly used models, Bilinear steel model and Ramberg-Osgood steel model, were used. The strain-hardening modulus in the Bilinear steel model was used as in Annex C EC3 (EN 1993-1-1, 2005), Kemp et al. (Kemp et al., 2002) and literature. In the Ramberg-Osgood steel model, the parameter $n$ is calculated by Equation 5 and taken from literature.

$$
n=\frac{\log \left(f_{s u}\right)-\log \left(f_{s y}\right)}{\log \left(\varepsilon_{s u}\right)-\log \left(\varepsilon_{s y}\right)}
$$

It is suggested by EN 1993-1-5 (EN 1993-1-1, 2005), that the strain hardening coefficient $(\mu)$ is 0.01 in the approach of steel material behavior. On the other hand, Kemp et al. (Kemp et al., 2002) recommended that it be taken as 0.013 . This value was taken as 0.005 and worked with structural analysis (Elghazouli et al., 2008). In the studies by Wang (2011), 0.013 remained very high (for steel elements), while the value of 0.01 converged, but still gave high results. In the context of the subject, it is important to examine the effect of concrete on this situation in composite elements.

As a result, strain hardening parameter is used in calculations as $0.005,0.01$, and 0.013 for Bilinear steel model, while in Ramberg-Osgood steel model, in addition to the value found by calculation, $n=20$ value, which is widely used in the literature, was used for examination purposes in the models.

While $\mathrm{f}_{\mathrm{sy}}$ and $\varepsilon_{\mathrm{sy}}$ are the yield stress and elongation of the steel, respectively, $\mathrm{f}_{\mathrm{su}}$ and $\varepsilon_{\mathrm{su}}$ are given as the ultimate stress and elongation of the steel, respectively. SeismoStruct software images of Mander concrete model, Bilinear steel model and Ramberg-Osgood steel models are given in Figure 1.

The column elements are modeled with the inelastic force-based frame element type. This is a force-based 3D beam-column element type that can model elements of space frames with geometric and material nonlinearities. In this element modeling technique, element sections are divided into fiber elements as given in Figure 2a. It also uses distributed elasticity elements as shown in Figure $2 b$ during calculations. Distributed elasticity elements are widely used in earthquake engineering applications for both research and professional engineering purposes. 


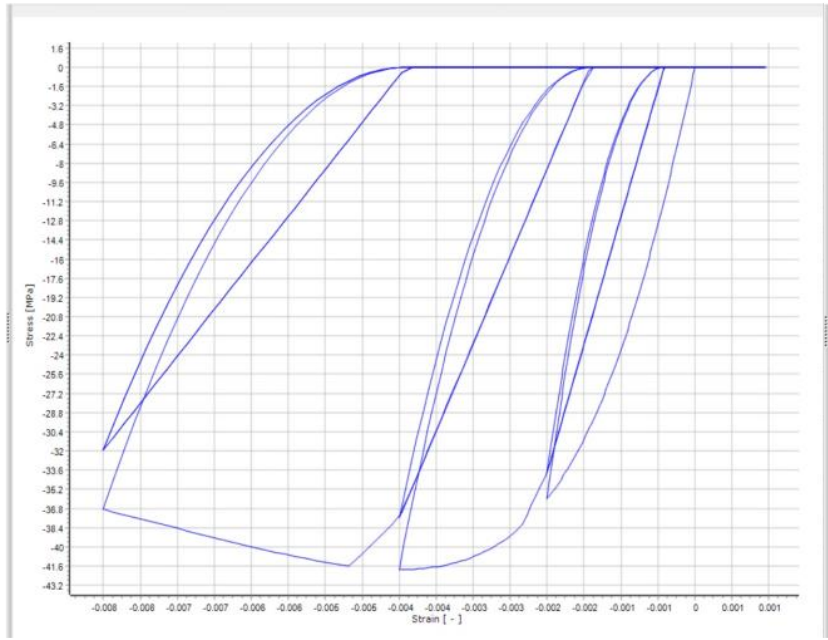

(a)

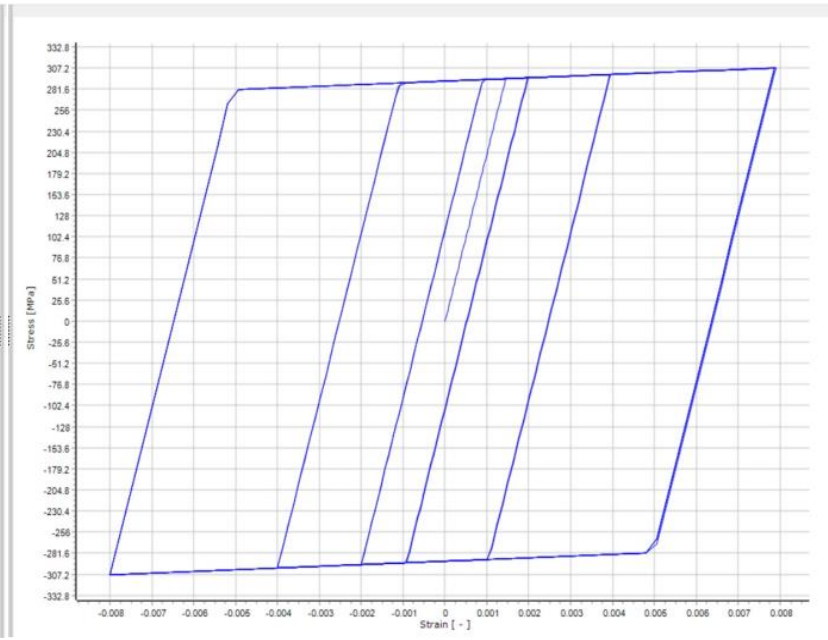

(b)

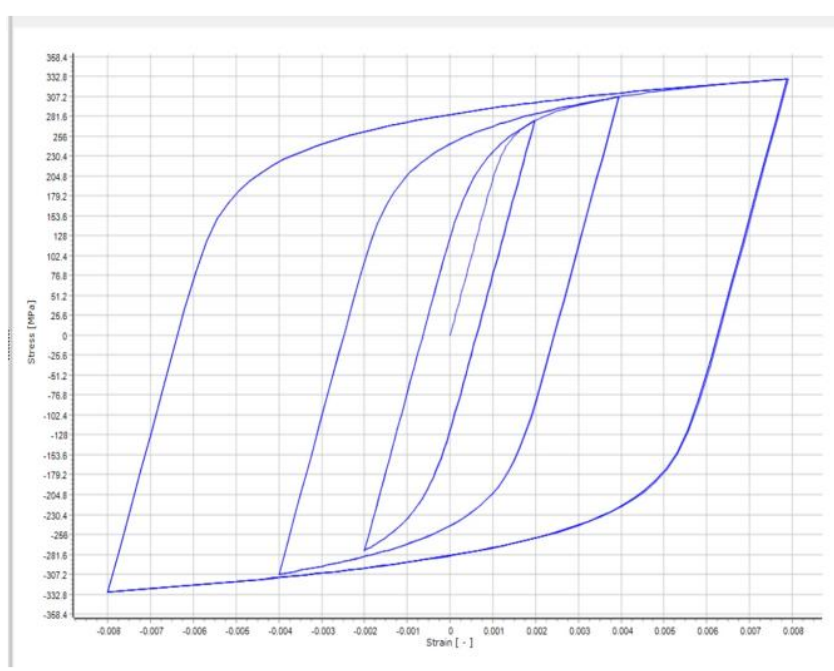

(c)

Figure 1. Material models view from SeismoStruct software a) Mander concrete model, b) Bilinear steel model and c) Ramberg-Osgood steel model

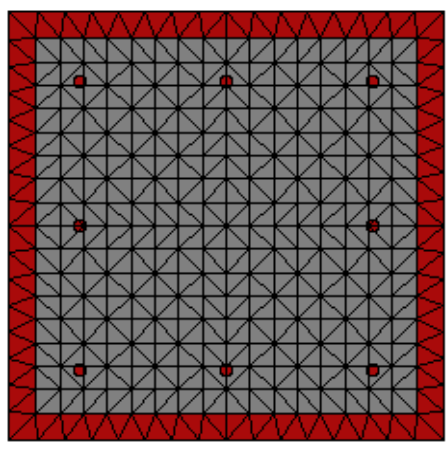

(a)

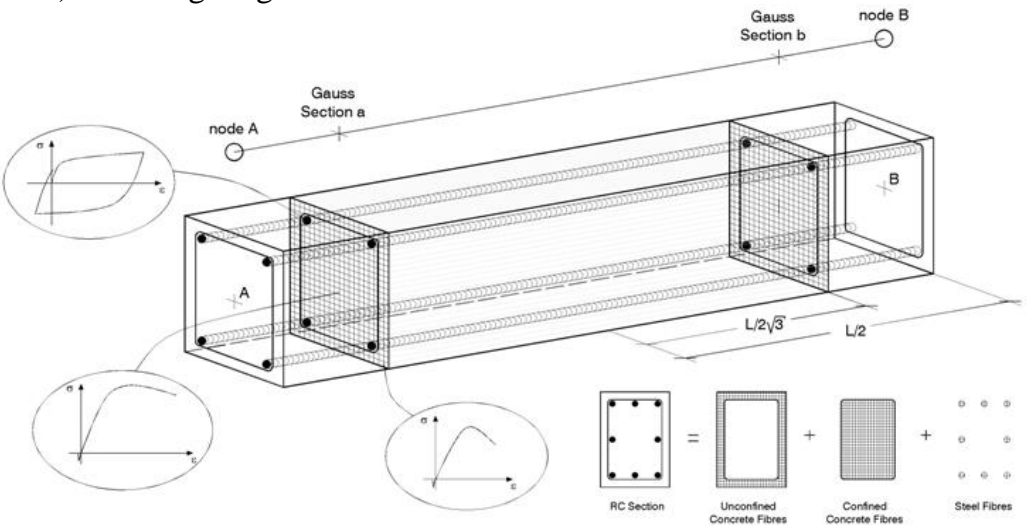

(b)

Figure 2. View from SeismoStruct software a) CFST column fiber section and b) Gauss sections 
Table 1. Specimen properties

\begin{tabular}{|c|c|c|c|c|c|c|c|c|}
\hline $\begin{array}{c}\text { Specimen } \\
\text { ID } \\
\end{array}$ & References & $\mathbf{f}_{\mathrm{cd}}(\mathbf{M P a})$ & $\mathbf{f}_{\mathrm{sy}}(\mathbf{M P a})$ & $\mathbf{E}_{\mathrm{s}}(\mathbf{M P a})$ & b (mm) & $\mathbf{t}(\mathbf{m m})$ & $\mathbf{l}(\mathbf{m m})$ & $v$ \\
\hline $4 \mathrm{LN}$ & \multirow{3}{*}{ (Tomii et al., 1977) } & 18.1 & 294.3 & 203067 & 150 & 4.3 & \multirow{5}{*}{450} & \\
\hline $4 \mathrm{MN}$ & & 27.8 & 294.3 & 203067 & 150 & 4.3 & & \\
\hline $4 \mathrm{HN}$ & & 36.4 & 294.3 & 203067 & 150 & 4.3 & & \\
\hline CR4-A-2 & \multirow{2}{*}{ (Baba et al., 1995) } & 25.4 & 261.2 & 213000 & 148.4 & 4.38 & & \\
\hline CR4-A-4 & & 40.5 & 261.2 & 213000 & 148.4 & 4.38 & & \\
\hline 27 & (Grauers, 1993) & 33 & 379 & 200000 & 250 & 8 & 500 & \\
\hline S1 & \multirow{5}{*}{$\begin{array}{c}\text { (Srinivasan \& Schneider, } \\
1999)\end{array}$} & 30.454 & 356 & 180518 & 127 & 3.15 & \multirow{5}{*}{609.6} & \\
\hline S2 & & 26.044 & 357 & 190164 & 127 & 4.34 & & \\
\hline S3 & & 23.805 & 322 & 205322 & 127 & 4.55 & & \\
\hline S4 & & 23.805 & 312 & 203944 & 127 & 5.67 & & 0. \\
\hline S5 & & 23.805 & 347 & 204633 & 127 & 7.47 & & \\
\hline A1 & (Ding et al., 2016) & 35 & 257 & 206000 & 240 & 4 & 720 & \\
\hline I-A & \multirow{4}{*}{ (Tomii \& Sakino, 1979) } & 32 & 194 & 210000 & 100 & 2.29 & \multirow{4}{*}{300} & \\
\hline II-A & & 21 & 339 & 218000 & 100 & 2.2 & & \\
\hline III-A & & 21 & 288 & 210000 & 100 & 2.99 & & \\
\hline IV-A & & 20 & 284 & 230000 & 100 & 4.25 & & \\
\hline CR4-A-4-1 & \multirow{3}{*}{$\begin{array}{c}\text { (Sakino \& Ishibashi, } \\
\text { 1985) }\end{array}$} & 40.5 & 262 & 210000 & 148 & 4.38 & \multirow{3}{*}{323} & \\
\hline CR4-C-4-1 & & 41.1 & 262 & 210000 & 215 & 4.38 & & \\
\hline CR4-D-4-1 & & 41.1 & 262 & 210000 & 323 & 4.38 & & \\
\hline
\end{tabular}

Within the scope of the study, the material and crosssectional properties of the experimental studies taken from the literature are given in Table 1. In Table 1, concrete compressive strength, steel yield strength, and Poisson ratio are given, respectively, with the symbols $\mathrm{f}_{\mathrm{c}}, \mathrm{f}_{\mathrm{sy}}, \mathrm{E}_{\mathrm{s}}$ and $v$ belonging to the experimental studies taken from the literature. In addition, section width, wall thickness and element heights are classified with $\mathrm{b}, \mathrm{t}$, and 1 symbols, respectively, in Table 1.

\section{RESULTS AND DISCUSSION}

The $\mathrm{k}_{\mathrm{c}}, \varepsilon_{\mathrm{co}}$ and $\mathrm{n}$ coefficients calculated from the data collected (Table 1) within the scope of the study. Using the data, the data obtained from the SeismoStruct software are presented on the graph together with the graphs obtained from the experimental results are given in Figure 3.

The results obtained by using the data obtained by the SeismoStruct software were mutually evaluated. A total of 5 graphs were calculated for each experimental element, with 3 strain hardening coefficient $(\mu)$ for Bilinear steel model and $2 \mathrm{n}$ coefficients for Ramberg-Osgood. In addition, 3 coefficients were obtained during the comparisons. 

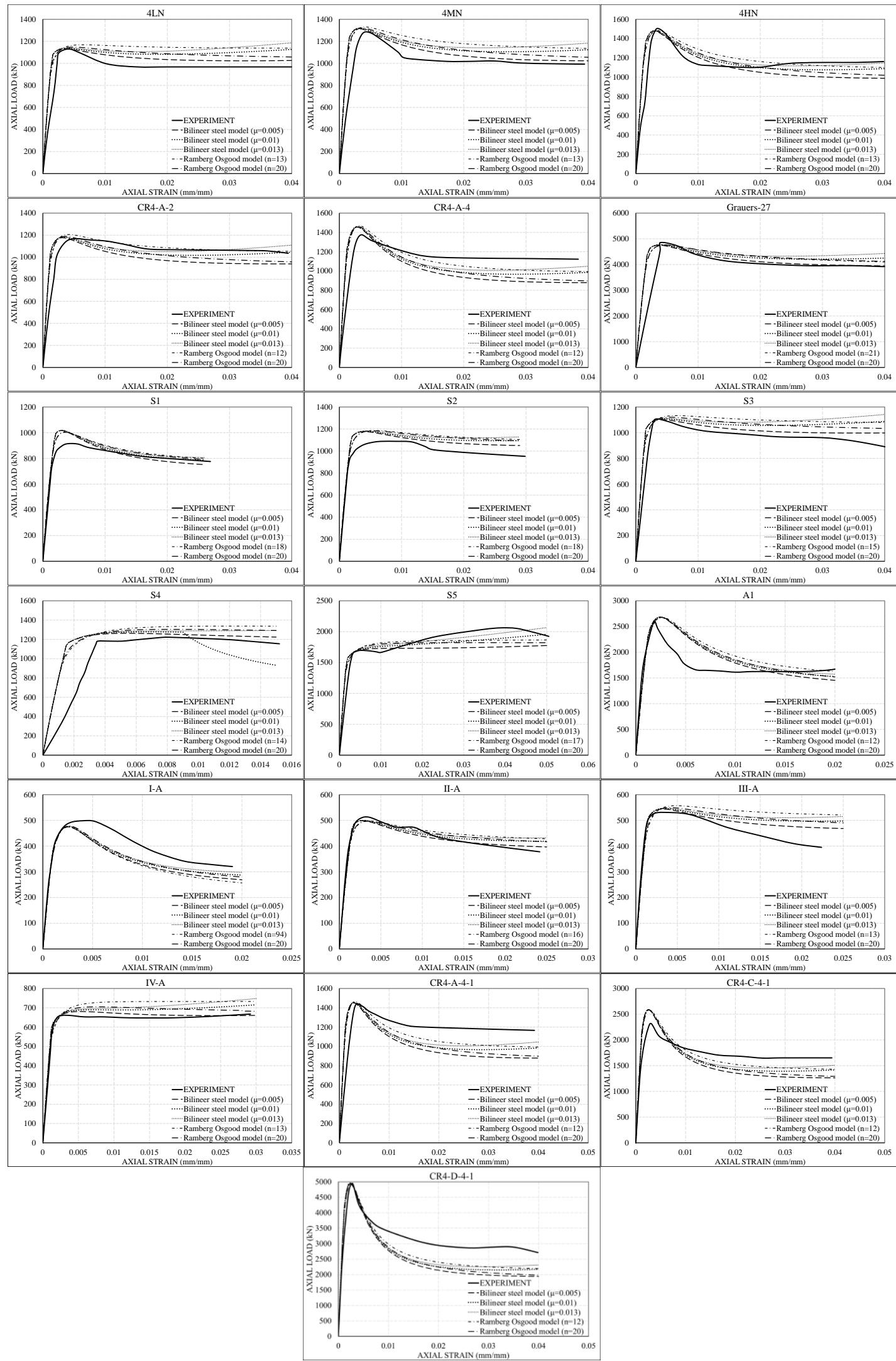

Figure 3. Axial displacement-load graph obtained from SeismoStruct software vs. experimental results 
Table 2. $N_{\text {ult,exp }} / N_{\text {ult,SeismoStruct }}$ coefficients

\begin{tabular}{c|c|c|c|c|c|c}
\hline \multirow{2}{*}{} & \multicolumn{6}{|c}{$\mathbf{N}_{\text {ult,exp }} / \mathbf{N}_{\text {ult,SeismoStruct }}$} \\
\cline { 3 - 7 } Specimen ID & $\mathbf{N}_{\text {ult,exp }}(\mathbf{k N})$ & $\boldsymbol{\mu}=\mathbf{0 . 0 0 5}$ & $\boldsymbol{\mu}=\mathbf{0 . 0 1}$ & $\boldsymbol{\mu}=\mathbf{0 . 0 1 3}$ & \multicolumn{2}{c}{ Ramberg Osgood model } \\
\hline 4LN & 1128.570 & 0.997 & 0.993 & 0.951 & 0.966 & 0.984 \\
\hline 4MN & 1278.570 & 0.973 & 0.969 & 0.967 & 0.961 & 0.968 \\
\hline 4HN & 1504.760 & 1.019 & 1.016 & 1.015 & 1.015 & 1.018 \\
\hline CR4-A-2 & 1167.860 & 0.992 & 0.988 & 0.985 & 0.968 & 0.982 \\
\hline CR4-A-4 & 1375.300 & 0.945 & 0.942 & 0.941 & 0.936 & 0.942 \\
\hline 27 & 4850.950 & 1.020 & 1.017 & 1.015 & 1.019 & 1.019 \\
\hline S1 & 912.338 & 0.898 & 0.896 & 0.895 & 0.909 & 0.909 \\
\hline S2 & 1088.260 & 0.925 & 0.922 & 0.920 & 0.917 & 0.919 \\
\hline S3 & 1103.880 & 1.002 & 0.996 & 0.967 & 0.974 & 0.985 \\
\hline S4 & 1222.730 & 0.968 & 0.957 & 0.946 & 0.914 & 0.937 \\
\hline S5 & 2061.690 & 1.161 & 1.054 & 0.998 & 1.105 & 1.131 \\
\hline A1 & 2596.840 & 0.969 & 0.967 & 0.966 & 0.970 & 0.970 \\
\hline I-A & 498.708 & 1.050 & 1.047 & 1.045 & 1.051 & 1.042 \\
\hline II-A & 512.432 & 1.028 & 1.025 & 1.024 & 1.030 & 1.031 \\
\hline III-A & 530.081 & 0.975 & 0.970 & 0.968 & 0.952 & 0.964 \\
\hline IV-A & 667.442 & 0.981 & 0.933 & 0.892 & 0.911 & 0.947 \\
\hline CR4-A-4-1 & 1432.870 & 0.987 & 0.984 & 0.983 & 0.978 & 0.984 \\
\hline CR4-C-4-1 & 2318.060 & 0.896 & 0.894 & 0.893 & 0.895 & 0.898 \\
\hline CR4-D-4-1 & 4944.470 & 0.996 & 0.995 & 0.994 & 1.000 & 0.999 \\
\hline
\end{tabular}

Firstly, $\quad \mathrm{N}_{\text {ult,exp }} / \mathrm{N}_{\text {ult,SeismoStruct }}$ are calculated (Table 2), while $\mathrm{N}_{\text {ult,exp }}$ and $\mathrm{N}_{\text {ult,SeismoStruct }}$ values represent the ultimate axial loading capacities obtained from experimental and SeismoStruct calculations, respectively. If the values of the $\mathrm{N}_{\text {ult,exp }} / \mathrm{N}_{\text {ult,SeismoStruct }}$ parameter are examined, in the analysis obtained, the strain hardening coefficient for the Bilinear steel model is 0.005 , with more than $52 \%$ of the samples reaching the values closest to the experimental data, but the obtained values converge between $0.2-7.5 \%$. In the models made with $\mathrm{n}_{\text {calculated }}$ coefficients together with the Ramberg-Osgood model, only $10 \%$ gave the values closest to the experimental results. On the other hand, all the results obtained from theoritically converge to the experimental results between $0.04-16.1 \%$. The highest diverge was obtained in the models made with $\mathrm{n}_{\text {calculated }}$ coefficients together with the RambergOsgood model for $42 \%$ of the elements (Table 2).

Secondly, $\mathrm{N}_{\text {exp }} / \mathrm{N}_{\text {SeismoStruct }}$ values were calculated (Table 3), as average of the ratio of experimental axial loading capacities $\left(\mathrm{N}_{\text {exp }}\right)$ to SeismoStruct experimental axial loading capacities $\left(\mathrm{N}_{\text {SeismoStruct }}\right)$ for each increasing strain value of 0.001. The $\mathrm{N}_{\text {exp }} / \mathrm{N}_{\text {SeismoStruct }}$ value acts as a kind of scaling factor. It can be considered as a scale of experimental graphic values to the values obtained from theoretical calculations. Similar to the $\mathrm{N}_{\text {ult,exp }} / \mathrm{N}_{\text {ult,SeismoStruct }}$ parameter value, the highest convergence was observed in $52 \%$ of the elements when the $\mu$ value used in the Bilinear steel model was 0.005. These convergence values vary between $2-17 \%$. On the other hand, when the $\mathrm{n}_{\text {calculated }}$ parameter with Ramberg-Osgood is used, more than $63 \%$ of the theoretical modeling studies are among the most divergent values according to the experimental results, and this divergence rate is in the range of 6$22 \%$ (Table 3 ).

Finally, the $A_{\text {exp }} / A_{\text {SeismoStruct }}$ coefficient (Table 4) indicates the ratio between the area under the graph obtained experimentally $\left(\mathrm{A}_{\exp }\right)$ and the area under the graph obtained theoretically from SeismoStruct ( $\left.\mathrm{A}_{\text {seismostruct }}\right) . \mathrm{A}_{\text {exp }} / \mathrm{A}_{\text {SeismoStruct }}$ value was evaluated as a second scaling coefficient within the scope of the study. It was evaluated as the ratio of the value of the area under the experimental axial displacement and load change graph to the value calculated as the graph area obtained from the theoretical calculations. Similar to the value of the $\mathrm{N}_{\text {exp }} / \mathrm{N}_{\text {SeismoStruct }}$ parameter, the highest convergence was observed in $52 \%$ of the elements when the $\mu$ value used in the Bilinear steel model was 0.005 . These convergence values vary 
between $1.5-16 \%$. On the other hand, when the $\mathrm{n}_{\text {calculated }}$ parameter with Ramberg-Osgood is used, more than $57 \%$ of the theoretical modeling studies are among the most divergent values according to the experimental results, and this divergence rate is in the range of $4-22 \%$.

Table 3. $N_{\text {exp }} / N_{\text {SeismoStruct }}$ coefficients

\begin{tabular}{c|c|c|c|c|c}
\hline & \multicolumn{3}{|c}{$N_{\text {exp }} / N_{\text {SeismoStruct }}$} \\
\cline { 2 - 6 } & \multicolumn{3}{|c|}{ Bilinear steel model } & \multicolumn{2}{c}{ Ramberg Osgood model } \\
\hline Specimen ID & $\mu=0.005$ & $\mu=0.01$ & $\mu=0.013$ & $\mathrm{n}_{\text {calculated }}$ & $\mathrm{n}=20$ \\
\hline 4LN & 0.920 & 0.879 & 0.856 & 0.846 & 0.886 \\
\hline 4MN & 0.908 & 0.868 & 0.847 & 0.836 & 0.975 \\
\hline 4HN & 1.026 & 0.978 & 0.953 & 0.988 \\
\hline CR4-A-2 & 1.037 & 0.984 & 0.956 & 0.942 & 1.002 \\
\hline CR4-A-4 & 1.094 & 1.035 & 1.004 & 0.990 & 1.056 \\
\hline 27 & 0.951 & 0.913 & 0.892 & 0.918 & 0.914 \\
\hline S1 & 0.977 & 0.957 & 0.946 & 0.941 & 0.946 \\
\hline S2 & 0.919 & 0.902 & 0.889 & 0.887 & 0.893 \\
\hline S3 & 0.935 & 0.896 & 0.876 & 0.876 & 0.900 \\
\hline S5 & 0.852 & 0.916 & 0.829 & 0.810 & 1.021 \\
\hline A1 & 1.060 & 1.008 & 0.980 & 1.005 & 0.917 \\
\hline I-A & 0.943 & 0.923 & 0.911 & 0.886 & 1.062 \\
\hline II-A & 1.093 & 1.065 & 1.048 & 1.111 & 0.928 \\
\hline III-A & 0.958 & 0.936 & 0.924 & 0.915 & 0.800 \\
\hline IV-A & 0.826 & 0.807 & 0.796 & 0.776 & 0.904 \\
\hline CR4-A-4-1 & 0.937 & 0.903 & 0.883 & 0.867 & 1.126 \\
\hline CR4-D-4-1 & 1.167 & 1.105 & 1.071 & 1.056 & 1.098 \\
\hline & 1.138 & 1.076 & 1.043 & 1.029 & 1.161 \\
\hline
\end{tabular}

Table 4. $A_{\text {exp }} / A_{\text {SeismoStruct }}$ coefficients

\begin{tabular}{c|c|c|c|c|c}
\hline \multirow{2}{*}{} & \multicolumn{3}{|c}{$\boldsymbol{A}_{\text {exp }} / \boldsymbol{A}_{\text {seismoStruct }}$} \\
\cline { 2 - 6 } & \multicolumn{3}{|c}{ Bilineer steel model } & \multicolumn{2}{c}{ Ramberg Osgood model } \\
\hline Specimen ID & $\mu=0.005$ & $\mu=0.01$ & $\mu=0.013$ & $\mathrm{n}_{\text {calculated }}$ & $\mathrm{n}=20$ \\
\hline 4LN & 0.933 & 0.892 & 0.869 & 0.858 & 0.899 \\
\hline 4MN & 0.925 & 0.886 & 0.864 & 0.854 & 0.953 \\
\hline 4HN & 1.036 & 0.993 & 0.968 & 0.961 & 1.001 \\
\hline CR4-A-2 & 1.054 & 1.002 & 0.973 & 1.004 & 1.065 \\
\hline CR4-A-4 & 1.100 & 1.046 & 1.016 & 0.934 & 0.930 \\
\hline 27 & 0.966 & 0.929 & 0.908 & 0.951 & 0.956 \\
\hline S1 & 0.985 & 0.967 & 0.956 & 0.897 & 0.903 \\
\hline S2 & 0.929 & 0.911 & 0.899 & 0.890 & 0.915 \\
\hline S4 & 0.949 & 0.911 & 0.889 & 0.848 & 0.863 \\
\hline S5 & 0.887 & 0.939 & 0.865 & 1.022 & 1.039 \\
\hline A1 & 1.078 & 1.025 & 0.996 & 0.879 & 0.906 \\
\hline I-A & 0.929 & 0.912 & 0.903 & 1.132 & 1.085 \\
\hline II-A & 1.115 & 1.088 & 1.072 & 0.930 & 0.944 \\
\hline III-A & 0.976 & 0.953 & 0.939 & 0.784 & 0.812 \\
\hline IV-A & 0.841 & 0.818 & 0.805 & 0.879 & 0.919 \\
\hline CR4-A-4-1 & 0.953 & 0.917 & 0.896 & 1.069 & 1.133 \\
\hline CR4-D-4-1 & 1.171 & 1.115 & 1.084 & 1.045 & 1.091 \\
\hline
\end{tabular}


Experimental studies on some parameter changes in the sample, such as $\mathrm{b} / \mathrm{t}$ changes, have been made on the effect of these parameters. In the analytical analysis methods used in the studies examined, if new models are proposed to affect this parameter on material models, the convergence is greater (Sakino et al., 2004). However, only the general material model is available in SeismoStruct. The aim of the study is to model the behavior of composite sections easily by the user using practical material models. For this reason, it can be observed that there are divergences between analytical results and experimental results in some models.

\section{CONCLUSION}

Experimental studies of CFST elements produced with SHS selected from the literature were re-examined using modeling techniques in SeismoStruct software. When the results of these material models and modeling technique, which are widely used in the literature, are examined comparatively within the scope of the study, the following conclusions are reached.

- When the $\mu$ value used in the Bilinear steel model is taken as 0.005 , the best convergences are obtained for $\mathrm{N}_{\text {ult,exp }} / \mathrm{N}_{\text {ult,SeismoStruct, }} \quad \mathrm{N}_{\text {exp }} / \mathrm{N}_{\text {SeismoStruct }}$ and $\mathrm{A}_{\text {exp }} / \mathrm{A}_{\text {SeismoStruct }}$ parameters in many modeled elements. This value is frequently used in theoretical and analytical analysis in the literature.

- For the $\mathrm{N}_{\mathrm{ult}, \mathrm{exp}} / \mathrm{N}_{\text {ult,SeismoStruct }}$ parameter, the change depends on the change in the $\mu$ and $n$ parameters, but diverges up to $16 \%$. In addition, when we look at the general results, this value has an average of $4-5 \%$ convergence for all.

- When the $\mathrm{N}_{\text {exp }} / \mathrm{N}_{\text {SeismoStruct }}$ parameter is examined, the closest values are obtained when the $\mu$ value used in the Bilinear steel model is taken as 0.005 , while the most divergent values diverge up to $28 \%$ from the experimental data when the $n$ value used in the Ramberg-Osgood steel model is taken as $\mathrm{n}_{\text {calculated. }}$ On the other hand, although there is an average of $8-10 \%$ error margin in $\mu$ and $n$ values, a convergence between $0.2-2.5 \%$ is observed, but a divergence range of $20-28 \%$ is also observed.

- Finally, when the $\mathrm{A}_{\mathrm{exp}} / \mathrm{A}_{\text {SeismoStruct }}$ parameter is examined, the closest values are obtained when the $\mu$ value used in the Bilinear steel model is taken as 0.005. Similar to the $\mathrm{N}_{\text {exp }} / \mathrm{N}_{\text {SeismoStruct }}$ parameter, the most divergent values diverge up to $25 \%$ from the experimental data when the $\mathrm{n}$ value used in the Ramberg-Osgood steel model is taken as $\mathrm{n}_{\text {calculated. }}$ On the other hand, an average of 89.5\% margin of error occurs in mu and $n$ values. In addition, while a convergence of $0.05-1.6 \%$ is observed in the most converging models, a divergence range of 19$25 \%$ is observed in the models where the largest differences occur.

\section{CONFLICT OF INTEREST}

The Author report no conflict of interest relevant to this article

\section{RESEARCH AND PUBLICATION ETHICS STATEMENT}

The author declares that this study complies with research and publication ethics.

\section{REFERENCES}

ACI 318-08. (2008). Building code requirements for structural concrete (ACI 318-08) and commentary.

AISC. (2003). Manual of steel construction, load and resistance factor design. Chicago: American Institute of Steel Construction, January.

Asteris, P. G., Lemonis, M. E., Nguyen, T. A., Le, H. V., \& Pham, B. T. (2021). Soft computing-based estimation of ultimate axial load of rectangular concrete-filled steel tubes. Steel and Composite Structures, 39(4), 471-491.

Ayough, P., Ibrahim, Z., Sulong, N. R., \& Hsiao, P. C. (2021). The effects of cross-sectional shapes on the axial performance of concrete-filled steel tube columns. Journal of Constructional Steel Research, 176,106424

Baba, T., Inai, E., Kai, M., T, N., \& Mukai, A. (1995). Structural behaviour of concrete filled steel tubular columns under axial compressive load, part 2: test results on rectangular columns. Abstracts of the Annual Convention of the Architectural Institute of Japan, 737-8.

Ding, F. X., Lu, D. R., Bai, Y., Zhou, Q. S., Ni, M., Yu, Z. 
W., \& Jiang, G. S. (2016). Comparative study of square stirrup-confined concrete-filled steel tubular stub columns under axial loading. Thin-Walled Structures, 98, 443-453. https://doi.org/10.1016/j.tws.2015.10.018

Elghazouli, A. Y.,_ Castro, J. M., \&Izzudd B. A. (2008). Seismic performance of composite moment-resisting frames. Engineering structures, 30(7), 1802-1819. https://doi:10.1016/j.engstruct.2007.12.004

Ellobody, E., \& Young, B. (2006). Nonlinear analysis of concrete-filled steel SHS and RHS columns. ThinWalled Structures, 44(8), 919-930. https://doi.org/10.1016/j.tws.2006.07.005

EN 1993-1-1. (2005). Eurocode 3. Design of steel structures. General rules and rules for buildings. In CEN (Vol. $3)$. https://doi.org/10.1017/CBO9781107415324.004

EN 1994-1-1. (2004). Eurocode 4: Design of composite steel and concrete structures - Part 1-1: General rules and rules for buildings. European Committee for Standardization, 3(February), 33-38. https://doi.org/10.1002/14651858.CD009305.pub2

Etli, S., \& Güneyisi, E. M. (2020). Seismic performance evaluation of regular and irregular composite moment resisting frames. Latin American Journal of Solids and Structures, 17(7), 1-22. https://doi.org/10.1590/1679-78255969

Etli, S., \& Güneyisi, E. M. (2021). Assessment of Seismic Behavior Factor of Code-Designed Steel-Concrete Composite Buildings. Arabian Journal for Science and Engineering, 46(5), 4271-4292. https://doi.org/10.1007/s13369-020-04913-9

Gadamchetty, G., Pandey, A., \& Gawture, M. (2016). On Practical Implementation of the Ramberg-Osgood Model for FE Simulation. SAE International Journal of Materials and Manufacturing, 9(1), 200-205. https://doi.org/10.4271/2015-01-9086

Ge, H. B., \& Usami, T. (1994). Strength analysis of concrete-filled thin-walled steel box columns. Journal of Constructional Steel Research, 30(3), 259-281. https://doi.org/10.1016/0143974X(94)90003-5

Grauers, M. (1993). Composite columns of hollow steel sections filled with high strength concrete. Chalmers University, Göteborg, Sweden.

Hajjar, J. F., Schiller, P. H., \& Molodan, A. (1998). A distributed plasticity model for concrete-filled steel tube beam-columns with interlayer slip. Engineering Structures, 20(8), 663-676. https://doi.org/10.1016/S0141-0296(97)00107-7

Han, L. H., He, S. H., \& Liao, F. Y. (2011). Performance and calculations of concrete filled steel tubes (CFST) under axial tension. Journal of Constructional Steel Research, 67(11), 1699-1709. https://doi.org/10.1016/j.jcsr.2011.04.005

Han, L. H., Li, W., \& Bjorhovde, R. (2014). Developments and advanced applications of concrete-filled steel tubular (CFST) structures: Members. Journal of Constructional Steel Research, 100, 211-228. https://doi.org/10.1016/j.jcsr.2014.04.016

Han, L. H., Lu, H., Yao, G. H., \& Liao, F. Y. (2006). Further study on the flexural behaviour of concretefilled steel tubes. Journal of Constructional Steel Research, 62(6), 554-565. https://doi.org/10.1016/j.jcsr.2005.09.002

Han, L. H., Yao, G. H., \& Tao, Z. (2007). Performance of concrete-filled thin-walled steel tubes under pure torsion. Thin-Walled Structures, 45(1), 24-36. https://doi.org/10.1016/j.tws.2007.01.008

Hu, H.-T., Huang, C.-S., Wu, M.-H., \& Wu, Y.-M. (2003). Nonlinear Analysis of Axially Loaded ConcreteFilled Tube Columns with Confinement Effect. Journal of Structural Engineering, 129(10), 13221329. https://doi.org/10.1061/(asce)07339445(2003)129:10(1322)

Hu, H. T., Huang, C. S., \& Chen, Z. L. (2005). Finite element analysis of CFT columns subjected to an axial compressive force and bending moment in combination. Journal of Constructional Steel Research, 61(12), 1692-1712. https://doi.org/10.1016/j.jcsr.2005.05.002

Kemp, A. R., Byfield, M. P., \& Nethercot, D. A. (2002). Effect of strain hardening on flexural properties of steel beams. Structural Engineer, 80(8), 29-35.

Lee, E.-T., Yun, B. H., Shim, H. J., Chang, K. H., \& Lee, G. C. (2009). Torsional Behavior of Concrete-Filled Circular Steel Tube Columns. Journal of Structural Engineering, 135(10), 1250-1258. https://doi.org/10.1061/(asce)07339445(2009)135:10(1250)

Li, P., Zhang, T., \& Wang, C. (2018). Behavior of Concrete-Filled Steel Tube Columns Subjected to Axial Compression. Advances in Materials Science and Engineering, 2018. https://doi.org/10.1155/2018/4059675

Liang, Q. Q. (2009). Performance-based analysis of concrete-filled steel tubular beam-columns, Part I: Theory and algorithms. Journal of Constructional Steel Research, 65(2), 363-372. https://doi.org/10.1016/j.jcsr.2008.03.007

Liang, Q. Q., \& Fragomeni, S. (2009). Nonlinear analysis of circular concrete-filled steel tubular short columns under axial loading. Journal of Constructional Steel Research, 65(12), 2186-2196. https://doi.org/10.1016/j.jcsr.2009.06.015

Ly, H. B., Pham, B. T., Le, L. M., Le, T. T., Le, V. M., \& Asteris, P. G. (2021). Estimation of axial loadcarrying capacity of concrete-filled steel tubes using surrogate models. Neural Computing and Applications, 33(8), 3437-3458.

Mander, J. B., Priestley, M. J. N., \& Park, R. (1988). Theoretical Stress-Strain Model for Confined 
Concrete. Journal of Structural Engineering, 114(8), 1804-1826. https://doi.org/10.1061/(asce)07339445(1988)114:8(1804)

Martínez-Rueda, J. E., \& Elnashai, A. S. (1997). Confined concrete model under cyclic load. Materials and Structures, $\quad 30(3)$, 139-147. https://doi.org/10.1007/BF02486385

Matsui, C. (1986). Strength and Deformation Capacity of Frames Composed of Wide Flange Beams and Concrete Filled Square Steel Tubular Columns. 169181. https://doi.org/10.3130/aijs.62.165_1

Ou, Z., Chen, B., Hsieh, K. H., Halling, M. W., \& Barr, P. J. (2011). Experimental and Analytical Investigation of Concrete Filled Steel Tubular Columns. Journal of Structural Engineering, 137(6), 635-645. https://doi.org/10.1061/(asce)st.1943-541x.0000320

Perea, T., Leon, R. T., Hajjar, J. F., \& Denavit, M. D. (2013). Full-Scale Tests of Slender Concrete-Filled Tubes: Axial Behavior. Journal of Structural Engineering, 139(7), 1249-1262. https://doi.org/10.1061/(asce)st.1943-541x.0000784

Richart, F. ., Brandzaeg, A., \& Brown, R. L. (2005). The failure of Plain and Spirally Reinforced Concrete in Compression. ACI Materials Journal, 10(29), 45-52.

Sakino, K., \& Ishibashi, H. (1985). Experimental Studies on Concrete Filled Square Steel Tubular Short Columns Subjected To Cyclic Shearing Force and Constant Axial Force. Journal of Structural and Construction Engineering (Transactions of AIJ), 353(0), $81-91$ https://doi.org/10.3130/aijsx.353.0_81

Sakino, K., Nakahara, H., Morino, S., \& Nishiyama, I. (2004). Behavior of Centrally Loaded ConcreteFilled Steel-Tube Short Columns. Journal of Structural Engineering, 130(2), 180-188. https://doi.org/10.1061/(asce)07339445(2004)130:2(180)

Schneider, S. P. (1998). Axially Loaded Concrete-Filled Steel Tubes. Journal of Structural Engineering, 124(10), $1125-1138$
9445(1998)124:10(1125)

Seismosoft. (2018). SeismoStruct A computer program for static and dynamic nonlinear analysis of framed structures V 7.0. www.seismosoft.com

Shanmugam, N. E., \& Lakshmi, B. (2001). State of the art report on steel-concrete composite columns. Journal of Constructional Steel Research, 57(10), 10411080 . 974X(01)00021-9

Srinivasan, C. N., \& Schneider, S. P. (1999). Axially Loaded Concrete-Filled Steel Tubes. Journal of Structural Engineering, 125(10), 1202-1206. https://doi.org/10.1061/(asce)07339445(1999)125:10(1202)

Thai, H. T., \& Kim, S. E. (2011). Nonlinear inelastic analysis of concrete-filled steel tubular frames. Journal of Constructional Steel Research, 67(12), 1797-1805. https://doi.org/10.1016/j.jcsr.2011.05.004

Tomii, M., \& Kenji, S. (1979). Elasto-plastic behavior of concrete filled square steel tubular beam-columns. Transactions of the Architectural Institute of Japan, 280, 111-122.

Tomii, M., \& Sakino, K. (1979). Experimental Studies on the Ultimate Moment of Concrete Filled Square Steel Tubular Beam-Columns. Transactions of the Architectural Institute of Japan, 275(0), 55-65. https://doi.org/10.3130/aijsaxx.275.0_55

Tomii, M., Yoshimura, K., \& Morishita, Y. (1977). Experimental Studies on Concrete Filled Steel Tubular Stub Columns Under Concentric Loading. International Colloquium on Stability of Structures under Static and Dynamic Loads, 718-741.

Wang, F. (2011). A deformation based approach to structural steel design. Imperial College London, $\mathrm{PhD}$ thesis. 